\title{
A new economic order for global prosperity
}

\author{
Raphael Louis
}

\author{
H.E. Hon. Sir. Dr., Leader-President/CEO, Lt. General (OSP), FAAVM, NCPC, OSP; Ontario, Canada
}

\begin{abstract}
The New International Economic Order (NIEO) was a set of proposals put forward during the 1970s by some developing countries through the United Nations Conference on Trade and Development to promote their interests by improving their terms of trade, increasing development assistance, developed country tariff reductions, and other means. It was meant to be a revision of the international economic system in favor of the Third World countries, replacing the Bretton Woods system, which had benefited the leading states that had created it. The term was derived from the Declaration for the Establishment of a New International Economic Order, adopted by the United Nations General Assembly in 1974, and referred to a wide range of trade, financial, commodity, and debt-related issues (1 May 1974, A/RES/S-6/3201). This followed an agenda for discussions between industrial and developing countries, focusing on restructuring of the world's economy to permit greater participation by and benefits to developing countries (also known as the "NorthSouth Dialogue"). Along with the declaration, a Program of Action and a Charter of Economic Rights and Duties of States (12 December 1974, A/RES/29/3281) were also adopted.
\end{abstract}

Keywords: economic stability, economic growth, fair trade, economic prosperity, sustainability.

JEL Classification: E20, N30, F13, I38, O15.

DOI: $10.21272 / \mathrm{sec} .1(2) .52-59.2017$.

(C) The Author, 2017. This article is published with open access at ARMG Publishing.

\section{Introduction}

The process of economic globalization has been under way for some time. It has brought great benefits to many millions of people in the developing world, with the potential to influence positively a billion more. Improvements in infrastructure, agriculture and industrial efficiency have led in turn to advances in health care and education. The increasing wealth of developing countries has yet to bring them close to the standard of living of advanced economies, but even so the world's average wealth, defined as GDP per head, is being spread more evenly with each successive year. Indeed, the economic power of the developing economies is now such that to some extent they can grow independently of the developed world and have found their own momentum, beginning a process of industrialization that encompasses more than 1.5 billion people.

The developed world should be thankful for this trend. As consumers in the advanced economies retrench from unsustainable levels, American consumer spending alone accounts for $21 \%$ of global GDP, shoppers in the BRICs will take up the slack. But there are also concerns, the critical one being to what extent this economic power will manifest itself as political power; a process that history suggests is inevitable. So perhaps the more pertinent questions are: how will these countries exercise this power? Will they want better terms in deals over climate change, for instance? Or want to keep an increasing portion of the world's natural resources for themselves?

I am an optimist and I believe that as the world's economy becomes more interdependent, we will see better collaboration. We must hope that the developed economies will become more generous with their intellectual property and financial resources; and, in return, that the emerging economies will supply not just their raw materials and cheaper workers, but more importantly their sheer human vitality and inventiveness. You don't have to travel far to see that this is already happening. In 2009, we may not know the absolute answer to the fundamental question of how the new map of economic power will be drawn. But the question is the most important of this relatively new century. We are living through a pivotal time in establishing a new economic order. What matters is that globalisation has started and in my view, it cannot and indeed should not be stopped. 


\section{Literature review}

\section{Free trade and fair trade}

Everyone knows there is a lot of poverty and inequality in the world. About half of the world's population lives on the equivalent of what two dollars a day would purchase in the US. The world's 358 richest people have more money than the combined annual incomes of countries with $45 \%$ of the world's population. Many argue that those who believe massive poverty and inequality are morally unacceptable have reason to support free trade. Often these people believe that 1) poverty is decreasing, 2) inequality is decreasing or at least not increasing and 3) free trade is contributing to these trends. In part, therefore the international financial institutions, like the World Trade Organization (WTO), the World Bank, and International Monetary Fund (IMF) promote free trade. The World Bank cites correlations between free trade and growth and finds evidence that the rising tide lifts all boats.

As shown in the chart, there is a pretty good correlation between household income inequality and the U.S. trade deficits from 1954 to 2012.

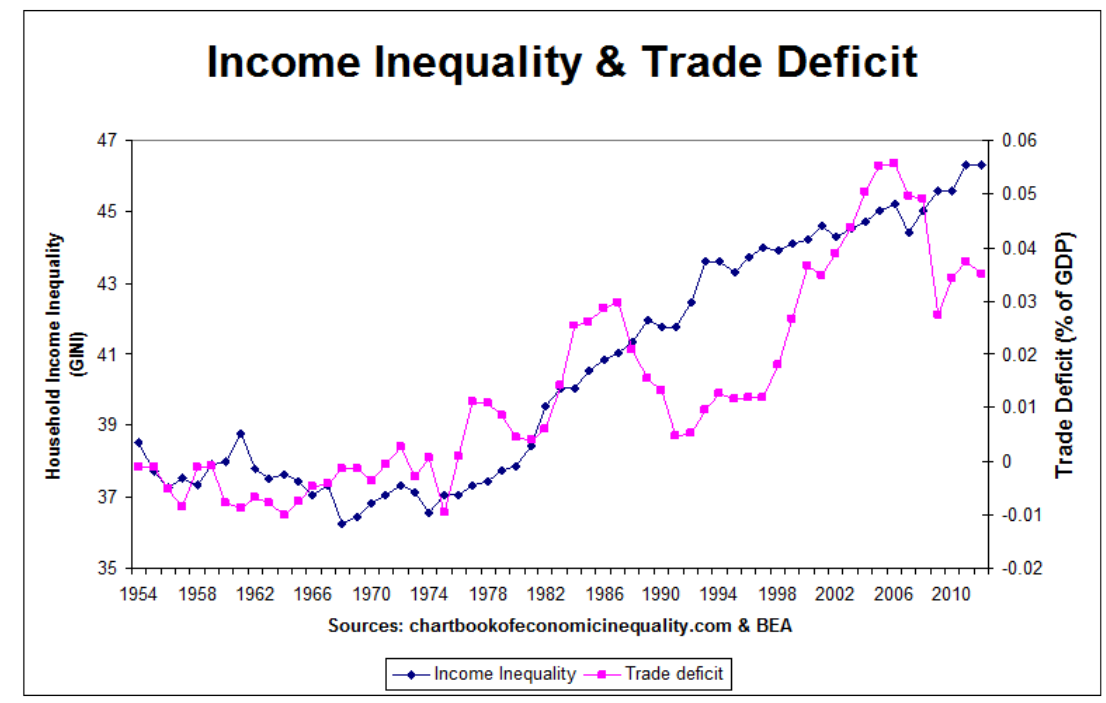

Figure 1. Income inequality and trade deficit

Source: chartbookofeconomicequality.com \& BEA.

Humans have traded with one another since the beginning of civilization. Trade gives us access to new foods, products and experiences, and creates economic opportunity and markets. Trade touches us all and has created incredible wealth for some; yet many remain impoverished and disenfranchised. To address marginalization and poverty in the global marketplace, "fair trade" has emerged to provide an alternative approach to trading, one based upon direct partnership and respect. Fair trade proves that greater justice in world trade is possible. It highlights the need for change in the rules and practice of conventional trade and shows how a successful business can also put people first. While many people are familiar with the term "free trade," few understand the negative impact of the institutions and agreements that regulate and promote "free trade." "Fair trade" principles have been juxtaposed below with corresponding Free Trade realities to illustrate the key differences in the two approaches to trade.

Official and non-government data sources, as well as reports of Chinese investment activities in the press, indicate that Chinese Foreign Direct Investment (FDI) is rising, both to the world and to the United States. While it is impossible to predict the precise value of U.S. FDI from China five years from now, it should be possible to make a rough ball park estimate based on the relationship between China's capacity to invest, reflected in its current account surplus and the profitability of its companies, and its proclivity to invest, reflected in its Foreign Direct Investment (FDI)-to-GDP ratio. An analysis of recent forecasts of China's current account balance, GDP, and corporate profits suggest China's investment capacity will expand over the next five years. Based on IMF forecasts from September 2011, China's current account is expected to remain in surplus over the next five years, rising to 7.2 percent of GDP by 2016. Using the exchange rate of 2011, this implies a current account surplus of approximately $\$ 912$ billion. Oxford Economic Forecasting 
("Oxford") predicts China's current account surplus will reach $\$ 450$ billion by 2016 . Both estimates exceed China's prior peak surplus of $\$ 411$ billion, which occurred in 2008 , prior to the collapse in trade resulting from the global financial crisis.

Both the Economist Intelligence Unit ("EIU") and Oxford publish estimates for China's outward FDI. The two forecasts are based on different assumptions regarding China's preference for recycling through FDI. EIU assumes that the share of Overseas Direct Investment (ODI) to Gross Domestic Product (GDP) will remain roughly constant in the range of 1-to-1.2 percent. On the other hand, Oxford's estimates imply that the ODI will rise to nearly 3 percent of GDP. Thus, there is a wide disparity between the two estimates: $\$ 140$ billion by EIU and $\$ 370$ million by Oxford. Both estimates far exceed China's actual outward FDI of nearly $\$ 70$ billion in 2010. Thus, even the more conservative of the two estimates has China's ODI doubling over the next five years. This prediction is consistent with those of other observers of China's ODI.

With China's GDP, current account surplus, corporate profits, and ODI likely to grow over the next five years, what are the likely U.S. inflows of Chinese FDI? The figure below presents three estimates compared to average capital inflows from Japan from 2003 to 2010. The "business as usual" scenario assumes that China's ODI remains at approximately 1.1 percent of GDP (the EIU assumption) through 2016 and that China's outflows to the United States as a share of total ODI are similar to 2009-2010. The "preference for ODI grows" scenario is based on the Oxford assumption that China's ODI is 2.9 percent of GDP by 2016. The "preference for ODI and U.S. grows" scenario adopts the Oxford assumption along with an assumption that the share of China's ODI devoted to the United States rises by 50 percent over 2009-2010. The implied growth rates for China's ODI to the United States are then applied to U.S. capital inflows from China in 2010. These scenarios suggest that China's ODI five years from now will be approximately 1.9 to 7.5 times higher than in 2010. Though such levels of inward FDI from China are higher relative to prior years, they remain well below average capital inflows from Japan. If these growth rates are applied to estimated flows on a Ultimate Beneficiary Owner (UBO) basis, then Chinese investments are likely to surpass the Japanese average by 2016 .

Develop new strategic industries energetically, such as energy-saving and environment-friendly newgeneration IT, biology, high-end equipment manufacturing, new energy sources, new materials and new energy automobile. In the energy conservation and environmental protection industry, focus on the development of key technological equipment for efficient energy conservation, advanced environmental protection and resource recycling, products, and services. In the new-generation IT industry, focus on the development of new-generation mobile communication, new-generation Internet, three-network convergence, Internet of things, cloud computing, IC, new displays, high-end software, high-end servers and information services. In the biological industry, focus on the development of biopharmaceuticals, biomedical engineering products, bio-agriculture and bio-manufacturing. In the high-end equipment manufacturing industry, focus on the development of aviation equipment, satellites and application, rail traffic equipment and intelligent manufacturing equipment.

In the new energy industry, focus on the development of new-generation nuclear energy and solar energy utilization, photovoltaic and photo-thermal power generation, and wind power technological equipment, intelligent power grids and biomass energy. In the new material industry, focus on the development of new functional materials, advanced structural materials, high-performance fibers and compound materials, and common basic materials. In the new energy automobile industry, focus on the development of plug-in hybrid electric vehicles, pure electric vehicles and fuel cell automobile technologies.

\section{NAFTA's Chapter 11 makes Canada most-sued country under free trade tribunals}

Canada is the most-sued country under the North American Free Trade Agreement and a majority of the disputes involve investors challenging the country's environmental laws, according to a new study. The study from the left-leaning Canadian Centre for Policy Alternatives (CCPA) found that more than 70 per cent of claims since 2005 have been brought against Canada, and the number of challenges under a controversial settlement clause is rising sharply. The investor-state dispute settlement mechanism contained in NAFTA's chapter 11 grants investors the right to sue foreign governments without first pursuing legal action in the country's court systems, in order to protect foreign investors from discrimination. Drafters of the 1994 treaty included the provision to protect U.S. and Canadian investors against corruption in Mexican courts. 
Critics argue that the mechanism limits governments from enacting policies on legitimate public concerns such as the environment and labour or human rights, and that negotiations are often carried out in secret. The CCPA believes the federal government's strong commitment to Chapter 11 and its willingness to settle and compensate claimants is encouraging more cases against Canada. There were 12 cases brought against Canada from 1995 to 2005, while in the decade since there have been 23. The 35 claims brought against Canada comprise 45 per cent of the total number of claims under NAFTA. That's significantly more than Mexico's 22 or the 20 brought against the U.S.

Canada has lost or settled six claims paying a total of $\$ 170$ million in damages, while Mexico has lost five cases and paid out \$204 million. The U.S., meanwhile, has won 11 cases and has never lost a NAFTA investor-state case. "Thanks to NAFTA chapter 11, Canada has now been sued more times through investor-state dispute settlement than any other developed country in the world," said Scott Sinclair, who authored the study. Canada is embarking on a new generation of multinational treaties such as the European Union free trade deal and the Trans Pacific Partnership, both of which contain investor-state dispute settlement (ISDS) systems. While governments can be sued under ISDS, there is no similar recourse for states to hold foreign investors, often wealthy corporations, accountable for their actions.

\section{What's the difference between fair and free trade?}

They may sound similar, but fair trade and free trade are often arch enemies. Fair trade places restrictions on farmers and producers. It forces them to pay minimum wages, adopt safe working conditions and pay lip service to planetary protection. Free trade removes all boundaries for all parties. It affords unfettered international export and import, free from taxes, tariffs, worker protections or pesky minimum wages.

Globally; fair trade makes things more expensive, free trade makes things cheaper; fair trade means workers earn more, free trade means workers earn less. So, while free does mean cheap, it also means we earn collectively less money with which to buy all that cheap stuff. Free trade is a bilateral agreement between countries to allow unrestricted import and export of goods. The advantage to free trade is that it taps into the efficiency of global markets. Free trade can spur economic growth while making goods less expensive. The downside is that all those goods get less expensive for a reason. It may be cheaper to build solar panels in China the US, which is fine. Who doesn't want cheaper solar panels! but those panels may be cheaper because workers are cheaper. So, in addition to importing affordable Chinese solar panels, we're exporting affable American jobs. Especially frightening for the fair-trade movement, free trade threatens to forgo worker protections and environmental standards Far from emancipating, free trade agreements such as the Trans-Pacific and Trans-Atlantic Partnerships threaten to force the world's least empowered workers into feudalism.

Free trade, on the other hand, encourages companies to look outside of their own country to get the goods they need, whether that be materials, products, foods, etc. If a Canadian company then finds that it's cheaper to import goods from another country now that there are no extra taxes, they will do so. This eliminates the need for the Canadian company to have these goods produced by workers in Canada, and as a result, many and many jobs are lost. A great example of a free trade agreement is the Trans Pacific Partnership, also known as the TPP. The TPP is the world's largest free trade agreement among 12 nations around the pacific. The TPP could have all kinds of negative ramifications including job losses to Canadian workers and our very own Teamsters 987 members in the dairy industry.

\section{Food waste, hunger, and climate change}

As a child, you likely heard some variation of the cliché, "Eat all your food; there are starving people in the world." While hunger remains one of humanity's greatest challenges, the underlying causes are not as clear as one might think.

Shockingly, one-third of all food produced for human consumption worldwide is lost or wasted. In the underdeveloped world, upwards of 600 million tons of food are lost annually due to poor infrastructure, lack of access to food processing facilities, and unfair markets. In the United States, 33.5 million tons of food waste are sent to landfills each year. The Food and Agriculture Organization of the United Nations (FAO) estimates that the direct cost to producers of food that goes to waste is currently $\$ 750$ billion annually, excluding the seafood industry. 


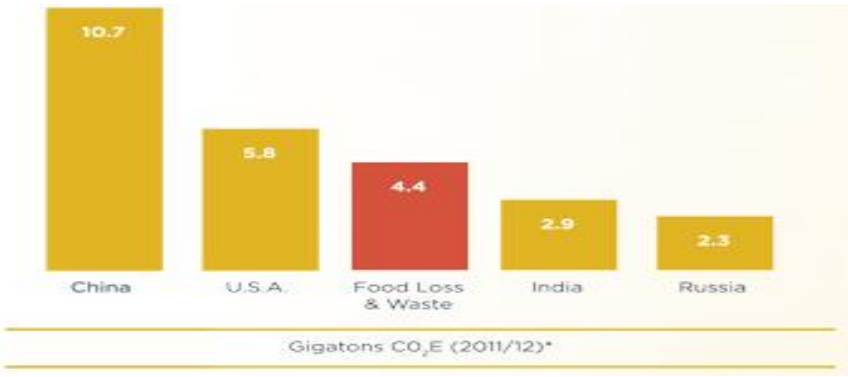

Figure 2. If food loss and waste were its own country, it would be the third-largest greenhouse gas emitter

Source: CAIT, 2015, FAO 2015. Food wastage footprint \& climate change.

Food waste and loss not only contribute to the global hunger crisis, with close to 800 million food-insecure people, but they account for a significant amount of greenhouse gas (GHG) emissions in the form of methane. According to the FAO, "Without accounting for greenhouse gas emissions from land use change, the carbon footprint of food produced and not eaten is estimated at 4.4 gigatons; billion tons of $\mathrm{CO} 2$ equivalent: as such, food waste ranks as the third top emitter after the U.S. and China." According to the Environmental Protection Agency (EPA), food waste in the United States accounts for approximately $17 \%$ of total methane emissions. And pound for pound, the comparative impact of methane on climate change has been twentyfive times greater than $\mathrm{CO} 2$ over a 100 -year period.

In the Global North, efforts are underway to reduce food waste at the consumer level by reducing portion sizes at restaurants, reforming food date labeling and educating consumers about proper food storage. Additionally, retailers and manufacturers can drastically reduce food waste by adopting widely available best practices. In the underdeveloped world, where most of the food loss occurs closer to farms and local communities, significant positive impacts can be gained via inexpensive investments in regional markets, refrigeration, and local transportation. Lastly, composting food waste and scraps, coffee grounds, banana peels, etc. can not only reduce methane emissions, but can return nutrients to the soil, close the nutrient cycle and even stimulate carbon sequestration. To have any impact, however, all these tactics and interventions must be institutionalized.

But, again, we should be clear about the true underlying causes of hunger. While addressing food waste and loss will reduce GHG emissions, it will not necessarily alleviate hunger. In fact, many countries that suffer from hunger, often also have food surpluses and/or export food abroad. At the global level, there is an overproduction of food, with more than enough to feed an ever-growing population. As Frances Moore Lappé has remarked, "Hunger is not caused by a scarcity of food but by a scarcity of democracy." Hunger, and food waste and loss, are symptoms of larger, structural issues, like debilitating national debts, unfair trade agreements and poverty. Indeed, addressing the root causes of hunger, food loss and climate change will require a radical transformation of the global food system.

Both intra-national and international inequality contribute to world inequality. International inequality contributes approximately $8 / 10^{\text {th }}$ of the total. This is because larger differences are usually found in two countries' mean incomes drawn randomly from the world than two individuals' incomes drawn randomly from one country. Still, increases or decreases in intra-national inequality might be compensated for by decreases or increases in international inequality. So, it is important to look at the components of world inequality to get the larger picture.

\section{Creating resilient prosperity in a community}

Most places have some elements of a renewal process. But with missing steps, their efforts tend to be unproductive or less-productive. The two most common gaps in the regeneration process are strategy and ongoing program. So, let's start by clarifying their roles in the overall process:

$>$ Visions guide actions to researched, desired outcomes;

$>$ Strategies drive actions to success;

$>$ Partners fund or support actions;

> Policies enable strategic actions; 
$>$ Plans organize actions;

$>$ Projects are actions;

$>$ Programs perpetuate, evaluate, and adjust actions. Ongoing programs create synergies, capture momentum (to grease the wheels for more projects), and inspire confidence in the local future.

Of those six action elements, the plan, which often takes longest to produce and approve will likely be obsolete the soonest. Complex systems (e.g. cities, ecosystems) resist rigid, imposed order. Note: Designing isn't listed separately in this process, because it's integral to several of the elements, such as visioning, planning, and projects.

"Successful revitalization efforts are driven by leaders and residents who are tirelessly strategic about identifying their competitive advantages."- Patrice Frey, President and CEO, National Main Street Center

Ironically, many places only have a plan. The common result is a plan without funding to implement it. Unfunded plans are so common that many folks consider them normal; they are often just for show, and shouldn't be allowed. The strategy supported by partners and policies should yield funding, since its job is to create success. Strategize first. Then plan. The fact that the strategy and the program are usually missing explains why most urban or regional revitalization and multi-jurisdictional environmental restoration such as watershed, river, or estuary initiatives are outright failures, or only marginally successful at best.

Some places work towards resilience or revitalization with a strategy and funding, but have no delivery process. When planners talk about design, it's usually about stuff: buildings, infrastructure, public spaces, etc. Good design is, of course, essential. But too many places rush into hiring designers before they have a strategy, or a process to deliver it. The frequent result? A design that shuts out strategic options. In those rare places that have a semblance of process, the element most commonly missing from that process is strategy. This is ironic, since strategy is the only element whose sole function is to help ensure success. The problem derives from focusing on successful completion of steps, rather than the overall goal. Mayors celebrate the completion of a new comprehensive plan, or a project design, as if that were an end unto itself. Without a strategy for success, this is just busywork.

We shouldn't ignore the power of design, though, since certain design-related needs appear to be in our genes. For instance, architects discuss a concept known as "prospect-refuge theory." It attempts to explain why some buildings and urban layouts make us feel secure and enriched, while others don't. First proposed in 1975, the premise is that we have a hard-wired need to observe prospect without being seen refuge. Our "observation" component apparently prefers complex places that offer the ability to explore and discover opportunities. So, good design must be embedded into the process.

Revitalization is a living process; a flow of ideas, images, relationships, and energy. "Stuff" is essential, but designing urban or regional resilience without designing a regenerative process is like basing personal wellness on buying exercise equipment, without ongoing exercise. Likewise, strategies live in the mind; they die on paper. Many folks confuse strategies with actions. Actions are tactics: strategies determine tactics. Others confuse strategies with goals. "Our strategy is to make this a greener or more equitable community". That's a goal.

A strategy is a technique that simplifies, speeds, and/or helps secure the achievement of a goal. Many factors contribute to success, of course, such as efficiency, quality of work, etc. But strategy is the only element of an endeavor whose sole function is to make it succeed. If it's a bad strategy or if the competition has a better strategy, failure is still possible. But without a strategy, failure is likely. The strategic disconnect is most damaging in policy making, where local, state/provincial, and national policies affect so much of what happens. Policies should execute strategies. Instead, most policies are tactical BAND-AIDs. This is mostly about economic not climate or disaster, resilience and sustainability. It uses "revitalization ", "resilience ", and "regeneration" somewhat interchangeably. They are three aspects of one dynamic. Today's emerging leading-edge strategy for both resilience and sustainability is based on repurposing, renewing, and reconnecting our natural, or built, and socioeconomic assets.

This applies to systems too, not just communities. For example, repurposing, renewing, and reconnecting our centralized, fossil fuel-based energy infrastructure into a distributed one based on diverse, renewable sources is an obvious starting point for anyone concerned with climate change, sustainability, or resilience. Public and private leaders tend to treat regeneration as if it has no essential underlying principles, frame- 
works, or components. They take whatever approach seems to be dictated by their available human, organizational, physical, and capital resources. Instead, we must adapt local efforts to the core revitalization process, not alter the revitalization process to fit local limitations.

\section{Production requires process}

A factory producing cars has a process. A school producing graduates has a process. A farmer producing corn has a process, as does a corn plant producing carbohydrates. Farmers might do a great job of tilling and fertilizing, and have excellent harvesting equipment. But if they don't plant the appropriate seeds, they get nothing but weeds. A community or region wishing to produce economic growth and enhanced liveability (revitalization) should have a comprehensive renewal process. But few cities have a self-improvement process, they just have activity. A plan here, a project there, and they hope it magically produces revitalization or resilience at some point.

\section{Conclusion}

Money can fix some problems, which leads those looking for simplistic solutions to assume it can fix most problems. The reality is far more complex, and can only be addressed with an adaptive, strategic, processoriented approach. The good news is that local governments are starting to realize how planning without a strategy wastes both resources and opportunities So, what is revitalization? Literally, it would be a return to a state of "vitalization" after a period of devitalization. But in normal usage, it generally means any significant improvement in quality of life, economic vibrancy, environmental health, social justice/harmony, and optimism. Ideally, all of those together.

Better futures are created by better actions in the present. But these days, people worldwide have been demoralized by the relentless globalization of social, economic, and environmental problems that used to appear only locally. Whether you're trying to make a community or nation more revitalized, more sustainable, or more resilient, all three goals require the same thing: a strategic process of repurposing, renewing, and reconnecting its natural, built, cultural, and socioeconomic assets. Revitalization is revitalization. And revitalization is the process of increasing the strength and vibrance of a living system in whatever way is appropriate to that system. One place might revitalize by increasing social justice, another by adding jobs, and yet another by restoring natural resources.

\section{References}

1. Andrew Szamosszegi (2012). An Analysis of Chinese Investments in the U.S. Economy, U.S.-China Economic and Security Review Commission October 2012, 145 p.

2. Howard Richman (October 10, 2015). Income inequality and the trade deficit. Retrieved from http://www.idealtaxes.com/post3917.shtml.

3. Lakshmi Mittal (2008). A new economic order [Online]. Retrieved from http://www.economist.com/node/12494647.

4. Ryan Zinn (March 1, 2011). Fair Trade vs. Conventional Free Trade: An Introduction, Fair World Project. Retrieved from https://fairworldproject.org/voices-of-fair-trade/fair-trade-vs-conventional-freetrade-an-introduction/.

5. Ryan Zinn (April 21, 2017). Food Waste, Hunger and Climate Change. Retrieved from https://fairworldproject.org/voices-of-fair-trade/food-waste-hunger-and-climate-change/.

6. Storm Cunningham (June 20, 2017). Resilience strategy guide. Retrieved from Revitalization News. http://revitalizationnews.com/how-to-revitalize/.

7. Sunny Freeman (2015). NAFTA's Chapter 11 Makes Canada Most-Sued Country Under Free Trade Tribunals. The Huffington Post Canada [Online]. Retrieved from http://www.huffingtonpost.ca/2015/01/14/canada-sued-investor-state-dispute-ccpa_n_6471460.html.

8. Teamsters (December 6, 2016). What is the difference between free trade vs. fair trade and why does it matter. Retrieved from http://www.teamsters987.com/free-trade-vs-fair/.

9. What's the difference between fair and free trade? The GlobeIn. Retrieved from https://globein.com/blog/fair-trade-vs-free-trade/. 